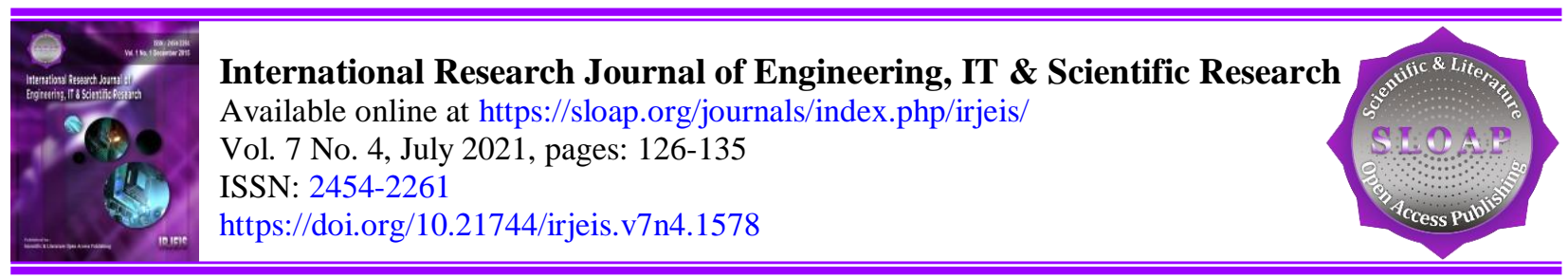

\title{
Promising Online Learning and Teaching in Digital Age: Systematic Review Analysis
}

\section{Article history:}

Submitted: 9 February 2021

Revised: 18 March 2021

Accepted: 27 April 2021

\section{Keywords:}

digital age;

online instruction;

systematic review;

teaching learning;

\begin{abstract}
This paper discusses online learning in the digital era by reviewing various international publications. This study is interesting given the growth of schools offering online education. This trend continues to develop, especially after the COVID-19 pandemic hit the world, which caused all social activities to stop. For that reason, we are interested in discussing online learning strategies, enriching the learning experience. Our analytical process involves coding, evaluation, and in-depth interpretation to obtain valid and reliable findings. We conducted data searches with the help of electronic searches on the Google Scholar app, ERIC publications, and Academic Microsoft between 2015 and publication in 2021. As a result, online educational activities have won a place in the hearts of students and teachers, which occur automatically through website technology. More specifically, this is called "e-learning." This is a promising distance learning that has become a trend for students and scientists and has become a way for people to get information about their needs.
\end{abstract}

International research journal of engineering, IT \& scientific research (C) 2021. This is an open access article under the CC BY-NC-ND license (https://creativecommons.org/licenses/by-nc-nd/4.0/).

\section{Corresponding author:}

Rahmat, A.

Institut Agama Islam Negeri Bengkulu, Indonesia

Email address: azwarrahmat90@gmail.com

\footnotetext{
${ }^{a}$ Institut Agama Islam Negeri Bengkulu, Indonesia

b STAI Rasyidiyah Khalidiyah Amuntai, Indonesia

c Universitas Bung Hatta, Indonesia
} 


\section{Introduction}

Internet utilities have become the trendiest and most well-known online instructional type these days since the COVID-19 pandemic hit the world last year. In fact, in the previous decade, online learning has significantly influenced schools and postgraduate degrees, and the pattern continues to develop not only in developed countries but also in developing countries (Carlesso, 2020; Ghosh \& Jing, 2020; Putra et al., 2020; Aslan et al., 2020; SUDARMO et al., 2021). This web-based learning is learning that occurs through Internet technology. It continues to expand at a faster rate than the larger student population. Schools must anticipate that the number of online students will grow to over 1.2 billion children globally are out of the classroom, and this will continue to grow in the coming year Huang et al. (2020). Most scientific pioneers from the health and education sector understand that online learning's quality and effectiveness when a country is hit by a pandemic that no one knows when it will pass, this online service is thought to be equivalent to or better than eye-to-eye guidance. Likewise, most of them are very enthusiastic that online instruction is engaging in the era of all digital trends, especially students who are currently in postgraduate (Aljawarneh, 2020). This study will investigate what a web-based learning experience looks like for students and how it has changed the educator's part. In other words, we want to prove whether online learning is a promising approach to modern learning (Powell et al., 2015; Antonoff et al., 2014; Oncu \& Cakir, 2011).

If online education is an effective way of digital day learning, it is questionable how it works. In previous years, educators needed to create their "virtual study space" without any troublesome preparation and regularly encourage helpless results (Raut, 2020). However, nowadays, entire industries have risen to do this for the advancement of education. Programming a technology-based education management system with the term multimedia is no longer foreign to almost all universities today (Huang et al., 2020). The system allows teachers to plan and deliver their courses in a customizable system that combines various tools to empower learning and correspondence (Rapanta et al., 2020). Multimedia systems and tools offer utilities that allow educators to convey course content more broadly and densely, empower content exchange and automated assessment. Most of the multimedia's essential tools include study schedules, syllabus, modules, chats, assignments, and daily tests and quizzes. One of these multimedia systems can be used by educators to create and handle a broader and faster learning prospectus (Harrington \& Thomas, 2018).

It may not be realized that online learning moves from top-down addressing and inactive students to more brilliant collective methodologies (Dover et al., 2020; Tsai et al., 2018; Davis et al., 2018). Learning constructivism in the digital era believes in keeping individual students effectively acquiring new information when communicating with their circumstances and learning in the advanced era. It is a student-focused learning methodology in which they "co-create" their learning experience. The teacher's job is to change from "wise man on stage" to "as and waiting for guide" in this era's learning methodology. Because this online learning methodology allows students to be dynamic individuals rather than just recipients of separate content is call promising as it allows Unique collaboration between organizers, educators, and students is very important using online instructional technology (Rapanta et al., 2020).

In any case, they are utilizing China's viable investigation during COVID-19 Prevention and Epidemic Control in Class 'On,' the World's Largest Online Education Today (15 March 2020). Utilizing the Internet and the Web to improve understudy instructing in conventional homerooms can be a great initial move towards finishing online training. An online educator ought to choose to perceive the anticipated learning-driven as identical to the regular worth model. People who run practical online classes should advocate facilitative learning and put stock in a system for making understudies effective. Online cycles and online communications rely upon facilitative techniques for their thriving. Educators ought to do all that could be within reach, not duplicate the homeroom in the field from an online perspective. They are instructing styles and patterns expected to teach on the Web. Online understudies are similarly occupied or busier than some other individuals in the present speedy world. Being refined, open, and versatile is compulsory for accomplishments in the online space.

Because the benefits of online learning are fundamental, it is not wrong to mention that online teaching and learning are some of the main benefits of web-based learning, including day-to-day access from any personal online set (Pandey et al., 2021; Papavlasopoulou et al., 2017; Zhao et al., 2014). Exploring various online learning resources in the digital era shows an expanded depth of understanding and explicit content maintenance. Reduce demand with a limited framework; deny nearby blockages. Efforts to provide alternatives for students to arrive in a new learning arena are beneficial. This is very interesting for students today who are born and live in an era where everything has been digitalized to expand the absorption of information and expertise. Web-based learning can also improve basic

Rahmat, A., Syakhrani, A. W., \& Satria, E. (2021). Promising online learning and teaching in digital age: systematic review analysis. International Research Journal of Engineering, IT \& Scientific Research, 7(4), 126-135. 
skills such as time management, independent learning, and self-control through personalized learning (Chung et al., 2020).

To make online learning a personalized way of learning, they must best have the Internet skills that come with it. Familiarity with Web programs and email programs is, among other things, beneficial (Jena, 2020). The online model underlines an intuitive learning climate intended to encourage learning content and transfer of skills between teachers and students. Courses are usually coordinated by weeks with exact due dates. They do not really "meet" in the constant or actual eye-to-eye sense. All things being equal, they cooperate consistently through multimedia assistance and via email (Evans et al., 2020). Even though the correspondence is fundamentally asynchronous, realtime visits can also be accessed. The model is coordinated, which means that the teacher and students can log in whenever it is advantageous each week. The best students are clever and effectively seek out questions and answers for subject areas and assignments (Garbe et al., 2020).

The advantages of online learning that make students independent have made most educators find that online learning provides a severe individual contact level with online students. This is because online classes allow for more time for reflection, dialogue, and collaboration. Online configurations, rather than becoming a deterrent to communication, promote and improve correspondence and coordination in respects that might be impossible in other situations. Take appearance style into account, condition, and particular abilities to see if being energizing on the Web is suitable for students. Some educators from an indigenous learning space climate will readily conform to the online model. Others may find change testing. Question: Computer literate. Is it accurate to say that students will overhaul their equipment or purchase a new program if necessary? Do students know how to use email and access the Web using the program?

Young \& Bruce (2011) have shown that the classroom and students' participation through online classes has modified electronic learning and instructional methods in almost all countries. The year of the online instructional course is ongoing. Online classes are structured to help students learn how to communicate with one another in an online world. Educational institutions ask instructors to share their perspectives on internet learning and educating on the Web. Schools need to hear from students: Do students think greeting is an extraordinary, fair technique for delivering on-the-ground instruction? Do students think that creating local area feelings among students is an educational need? The driving styles and inclinations expected to educate on the Web are genuinely effective. Can students provide several critical hours each week (anytime, day or night) based on flexibility and personalized learning to take part in educational actions via the internet? Is it possible that students can join and contribute to students' online homeroom chats and mingle with students online, four days a week, in an ideal world? Are students capable of making and sticking to their plans? Are students adaptable when it comes to fulfilling their needs? Is it fair to assume that students accept that rules can be communicated by composition (online classes are text-only)?

Wanner \& Palmer (2015) illustrate eight indicators of highlights practice for undergraduate education. The internet teaching exercise combines components in each of the seven zones; as shown below, online teachers should focus on students who may need additional assistance. Insights and staff can convey through private messages and informal meetings. Educators may utilize the promise of the highlights intelligence online through planning tasks to an appropriate website. Give learners more control, positions of authority, and alternatives on what tasks to complete. Consider combining peer surveys, project sharing, and stringing for in-person conversations. Online learning areas that consider student personnel contacts can also be used to encourage learner-to-learner contact. Informal discussions can help encourage group work and collaboration between students.

In the world of online learning, students can get their test results instantly and see answers to assignments reviewed after accommodation. Give students assignments and directions that they would say to expand fulfillment and nurture. In the prospectus of teachers, they must include course objectives, targets for carrying out authentic assessments. There is no excuse that all students should turn in the same homework or engage in the same conversation. Too many of the same things will confuse students in online classes where they have to reflect on students' different learning styles. Offer students something specific to respond to in each module by communication, for example. Work on each post's emphasis gift agreement and react to the discussion meeting's questions.

\section{Materials and Methods}

As previously mentioned, this research paper aims to discuss how promising online learning and teaching is in the technology age or digital era, where almost all lines of life are becoming technological trends. We have collected much literature about online learning and technology innovating education from various data sources such as Google 
Scholar, ERIC publications, Academic Microsoft, and other sources. Then our study began systematically. First, we seek to understand the problem formulation. Next is the development of the study protocol. Literature analysis involves coding, evaluation, and in-depth interpretation to obtain valid and reliable data findings. We followed the directions of a descriptive qualitative study in reporting the results of this study (Raskind et al., 2019) in their study of qualitative data analysis for health education.

\section{Results and Discussions}

In this section of findings, we present a description of the core findings of research to discuss how online learning in the era of digital technology is a promising solution for all educational communities and interested parties. The first study came from Ali (2020) who examined how web-assisted learning and distance learning in college-level training associations. Ali said this online learning model answers the need and to considers the response to the COVID-19 pandemic. Several tertiary educational institutions have been closed due to the increasingly global issue of COVID. Previously, digital learning was believed to have many obstacles, but after the issue of dynamics, online learning has found a good place among schools and universities that have emerged in guide structures worldwide for both developed and developing countries. It is now confident that the educational community needs an outer flexible tutoring structure as we face unusual possibilities. Disclosure is being offered on the web and distance learning as a necessity amid the lockdown and social isolation in light of the COVID-19 pandemic. This also provides a vital stage for extra investigations. It turns out that the wisdom of the arrival of the pandemic has not slimly made the education community aware of its adoption in the digital era. This is in line with the study of Sahlberg (2021) stating the Finnish Classes 3.0: How Will the Globe Benefit from Finland's Academic Transformation?

Meanwhile, Simamora (2020) findings highlight how web-based learning challenges during the COVID-19 pandemic have made academics aware of the massive role technology plays in bridging learning during the pandemic. Article exams to train students to expressive expressions. These findings are expected to dissect students' online learning patterns as a point of view or reaction to web-based distance learning difficulties during the COVID19 pandemic. This paper collects fifteen students as a test in the primary education I course who are effectively engaged with a web-based learning exercise. The analyst then collects, reads, and displays each student's reactions deemed usable for research. This paper has shown countless reactions to how students enjoy internet-based learning. It has shown positive and negative effects on the Web, the nature of learning, financial conditions, and challenges during web-based learning to think about and regulate challenges and information security for students through the internet network. Likewise with research (Bolliger et al., 2010) states that the effect of podcasting on student motivation in online learning environments, namely computer-based learning and digital education, is a concern.

Bączek et al. (2021) understand how understudies feel about web-based learning since students enter the technological era through a systematic review of Polish clinical student investigations. E-learning learning has become an intelligent strategy for showing educational plans for entering the advanced era. E-learning is considered less feasible than eye-to-eye learning as far as developing social skills and abilities. Implementing effective webbased learning requires thoroughly checked procedures and a more dynamic methodology. Most of the respondents chose the absence of cooperation with patients (70\%) and specific IT hardware problems (54\%) as the main weaknesses of e-learning. E-learning is rated as enjoyable by $73 \%$ of respondents and is an integral asset to present clinical students with but has to do with thoroughly vetted techniques.

Dhawan (2020) studied web learning as a panacea in times of the COVID-19 crisis and the digital era. Schools, colleges, and universities in India are generally established according to standard procedures for learning. The unexpected pandemic eruption of the deadly disease Covid-19, which was captured by the Corona Virus (SARS$\mathrm{CoV}-2$ ), forces teachers to switch to online teaching strategies until further notice. This article combines the concept of electronic learning to study the strengths, drawbacks, opportunities, and challenges of e-learning modes in an emergency. It also brings together ideas for research institutions on how to deal with the complexities of electronic learning. However, when talking about the digital era, the emergence of a pandemic unintentionally jumps into the world of learning with technology, and the results are really like a panacea (Alter, 2017).

Tafazoli et al. (2017) said personal computer proficiency: Sine qua non for advanced language learning and teaching. With the far reach and advancement of information and communication technology in everyday human life, innovation provides various freedoms and difficulties for foreign language educators and students. The excellence of studying a foreign language coordinates innovation for instructional purposes, indicating an interest in digital technology or electronic education for language instructors and students. Proficient educators and students can utilize

Rahmat, A., Syakhrani, A. W., \& Satria, E. (2021). Promising online learning and teaching in digital age: systematic review analysis. International Research Journal of Engineering, IT \& Scientific Research, 7(4), 126-135. 
various advances as instructive gadgets in their educational and learning paths. This paper audits related writing at new skill levels, such as the relationship between technological and electronic abilities in language learning and education is impressive (Nation \& Macalister, 2020).

Likewise, the finding of evidence that learning technology is very suitable for the digital era is from Robles (2013) who writes about using web tools in instructive ways through an innovative method in educator school courses. With a growing reliance on web resources, Web instructive tools have offered educators distinct freedom when compared to the limitation of traditional face-to-face learning. He researched the most suitable instructive devices to match the learning tendencies of their students. It can be proven, students in this advanced age need to find ways to create, collaborate, and share new data adequately and productively on the Web using various webaccessible tools for rooted learning (Munyoro, 2014).

Given the importance of online learning today, Hao \& Lee (2015) study of instructor anxiety about incorporating advances in Web 2.0 and its relationship to educator quality has been a fascinating subject. Their review research study analyzed 200 Taiwanese government teachers' anxieties about coordinating web 2.0 innovation in guidance. They found that there was a relationship between the attributes of educators and the types of teacher anxiety. These findings suggest that instructors' interest is generally severe in the educational, individual, and executive stages. Some of the consequences are shown for future investigations and project plans to increase instructor skills, especially the expertise to use technology to ease educators' concerns so that virtual learning is the most effective strategy for entering the digital era (Palloff \& Pratt, 2013).

Furthermore, Avidov-Ungar \& Forkosh-Baruch, (2018) findings regarding how the character of technologycapable teachers in high school secondary school take into account the demands of academic development through technology are essential. Their study looks at the instructor teacher's insight into academic progress, especially mastery of learning technology. To prove their study's purpose, 27 semi-organized meetings were dissected using three attendance methods that shaped their expert character of technological academic progress, which made the segment count, do the excellent segment, and have a natural help section. The findings show that the excellent character segment for technology is the dominant presentation method and is firmly linked to technologists' selfdevelopment. Also, teachers demand computerized teacher instructors to reconsider their expert personalities versus digitally coordinated educational innovations. Government institutional assistance is essential for the development of a professional personality in the technology era. These findings help understand the development of the skilled character of imaginative and innovative instructor teachers as technology enters the digital era in all things life and education (Fox \& Schirrmacher, 2014).

Huda \& Teh, (2018) examined activeness and proficiency in the practice of intelligence in computerized teaching. In this era of technology, intelligent teaching practice has been considered to pay attention to programs and arrangements that must be carried out using technological means. Nonetheless, computerized time has moved to show practice from direct association to virtual practice. It has difficulties such as professional proficiency at webbased mastery. This section aims to fill this gap by proposing a structural model of intelligent encouraging practice to give due consideration to technologically polished methodologies and the embodiment of teaching ethics to be appropriately treated among school leaders. This section can enhance instructor learning and skill enhancement, which should be viewed as a process with steps that combines formal, non-formal, and casual awareness so that students will have the opportunity to reflect directly even though instructional practice with technology consists of the distinctive way in different settings (Seels \& Richey, 2012).

Moreillon (2015) extends intuition in the climate of internet learning by using sophisticated instruments to help students make socially constructed interests. The study of instructional technology has been cited as a factor in attracting and retaining students in online courses and projects. Teachers can reach beyond the internet to study executive frameworks for finding promising web-based tools. These exercises and tools can help staff as they institutionalize social constructivist teaching theory. This paper describes teachers' journey in expanding their abilities and using Web 2.0 tools to support students in learning the technology era (Sadaf et al., 2012).

\section{Discussions}

Based on a review of several papers on the effectiveness of online learning in the digital or millennial era, we will present the language related to the above results section's findings in this part of the discussion. So since the technology was introduced in the curriculum in every school globally and since the COVID-19 pandemic hit the world, online learning activities have become more trendy and global. The extent to which this online learning is connected and promising in today's advanced era is what we have studied. 
So the question arises, what is online learning? The journal review above can be answered that when learners take classes online, not in real classrooms, it means that the learners are referred to as online learning. If conditions do not allow students to attend school, study, and practice independently, or if students live too far from college, online learning may be right for them. Students will do the following for online learning that must be working full time and researching simultaneously. So learning the technology-assisted virtual way is an auspicious way. Similar findings were also made by Jolliffe et al. (2012) who said that online learning is an effort to develop advanced learning methods and internet networks that are not bound by space. Likewise, the findings of Luo et al. (2017) who successfully designed authentic learning activities to train pre-service teachers how to teach online. Their study has answered our assumption that online learning is now a world trend in the era of advanced technology through open studies and collaborative learning.

From the series of publications we reviewed, most publications have unique reasons why online learning is so relevant that it is a promising activity in the digital era, including online learning that is easy to adapt to all circumstances, especially when the world is suffering Covid-19. For example, they say that online lectures empower teachers and students to set their own pace of learning, and there are additional scheduling adjustments to accommodate everyone's plans. Therefore, using the online learning stage considers a superior balance of work and learning, so there is no compelling reason to give up not using it. In other words, web-based learning shows us the flexibility of time, which makes online learning activities simpler to balance the lecturer-student role. In other words, they have a unique plan between lecturer and educator roles, which can provoke both parties to accept a new, more independent role. Likewise, Muir et al. (2019) which proves balanced involvement between lecturers and students' online learning experience, is correct.

Another reason for online learning is that it offers an infinite variety of options where there are limitless abilities and subjects to educate and learn in a vast space as the Web. More and more educational institutions are offering their learning projects on the Web for various levels and teaching. From artwork to quantum physics, there is a possibility for every type of substitution. Online education programs are also an excellent option for gaining recognition or an authority degree without actually going to classrooms. He (2014) in his study on online learning design for improving teacher education projects. In this way, it allows the learners' confidence to learn more online.

Another advantage of online learning is the element of openness. Online education empowers students to study or teach from anywhere in the world. The majority of articles confirm that has no more reason to undertake learning from one place to another or follow an inflexible schedule. In addition to saving time, students also save money, which can be used for various purposes. The virtual homeroom teacher is also accessible wherever there is a web association, and the best way to use it is by traveling. For example, if students are concentrating abroad and need to find a new job, online education is good. There is no reason to stop working or contemplate while exploring new and extraordinary places. The study of Yuan et al. (2014) also supports the findings above to explore sustainable online learning in various institutions. It takes into account shifting learning experiences.

The following reason is that online classes are generally simpler than regular class sizes. More often than not, the web-based learning stage only allows each student to take turns, and in almost all cases, this assumes more prominent communication and more criticism between the student and the teacher guide. There is often access to various materials such as audio, photos, and eBooks, and guides can also incorporate different arrangements such as meetings or conversations to improve their practice. What is more, these additives can be accessed anytime from anywhere, making it easier for more robust and specific instructions (Bolliger et al., 2010).

Smarter financially than conventional instruction. Unlike face-to-face teaching strategies, online training generally makes more sense. Many installment options allow the teacher to pay in portions or per class. It takes executives' spending better into account. Most of the students may also be subject to restrictions or grants, so fees are rarely high. Teachers can also set aside cash from classroom drives and materials, often available free of charge. So, there is less financial effort, but the results can be superior to different alternatives. Final consideration These are some of the motivations for choosing online teaching, and why $90 \%$ of students today imagine that Internet learning is something very similar or better than conventional learning-room experiences. Each student should review their state of interest and conclude according to their needs and goals, and given that this option is different from conventional training, which is not for everyone, it is still a practical alternative with practically unlimited options for global students everywhere this world. Panigrahi et al. (2018) support virtual instruction as flexible, progressive, and learning outputs.

Rahmat, A., Syakhrani, A. W., \& Satria, E. (2021). Promising online learning and teaching in digital age: systematic review analysis. International Research Journal of Engineering, IT \& Scientific Research, 7(4), 126-135. 


\section{Conclusion}

To conclude this review, we would like to summarize our findings based on reviewing several publications' findings to understand how online learning can be a promising solution for learning in the digital age. Several findings from the above studies have confirmed hi [potesa we have answered this study's problem. There are several reasons that online learning can be a promising solution in the all-digital era with all the advantages and high flexibility as we described in the discussion section and findings above. Finally, we conclude that these findings are beneficial for many people to accelerate studies and learn in an advanced and millennial era.

Conflict of interest statement

The authors declared that they have no competing interests.

Statement of authorship

The authors have a responsibility for the conception and design of the study. The authors have approved the final article.

\section{Acknowledgments}

The authors thank all colleagues for their support of this project from start to finish. Likewise, without financial support from universities, especially the Ministry of Research and Technology, this work is greatly helped. For all moral and material support, we thank all. 


\section{References}

Ali, W. (2020). Online and remote learning in higher education institutes: A necessity in light of COVID-19 pandemic. Higher Education Studies, 10(3), 16-25.

Aljawarneh, S. A. (2020). Reviewing and exploring innovative ubiquitous learning tools in higher education. Journal of Computing in Higher Education, 32(1), 57-73.

Alter, A. (2017). Irresistible: The rise of addictive technology and the business of keeping us hooked. Penguin.

Antonoff, M. B., Verrier, E. D., Yang, S. C., Lin, J., DeArmond, D. T., Allen, M. S., ... \& Vaporciyan, A. A. (2014). Online learning in thoracic surgical training: promising results of multi-institutional pilot study. The Annals of thoracic surgery, 98(3), 1057-1063. https://doi.org/10.1016/j.athoracsur.2014.04.062

Aslan, A., Silvia, S., Nugroho, B. S., Ramli, M., \& Rusiadi, R. (2020). Teacher's leadership teaching strategy supporting student learning during the covid-19 disruption. Nidhomul Haq: Jurnal Manajemen Pendidikan Islam, 5(3), 321-333. https://doi.org/10.31538/ndh.v5i3.984

Avidov-Ungar, O., \& Forkosh-Baruch, A. (2018). Professional identity of teacher educators in the digital era in light of demands of pedagogical innovation. Teaching and Teacher Education, 73, 183-191.

Bączek, M., Zagańczyk-Bączek, M., Szpringer, M., Jaroszyński, A., \& Wożakowska-Kap\lon, B. (2021). Students’ perception of online learning during the COVID-19 pandemic: A survey study of Polish medical students. Medicine, 100(7).

Bolliger, D. U., Supanakorn, S., \& Boggs, C. (2010). Impact of podcasting on student motivation in the online learning environment. Computers \& Education, 55(2), 714-722.

Carlesso, A. (2020). Distance Education and Emergency Remote Teaching: An Analysis of the Italian School System Affected by the COVID-19 Pandemic.

Chung, E., Subramaniam, G., \& Dass, L. C. (2020). Online Learning Readiness among University Students in Malaysia amidst COVID-19. Asian Journal of University Education, 16(2), 46-58.

Dhawan, S. (2020). Online learning: A panacea in the time of COVID-19 crisis. Journal of Educational Technology Systems, 49(1), 5-22.

Davis, D., Chen, G., Hauff, C., \& Houben, G. J. (2018). Activating learning at scale: A review of innovations in online learning strategies. Computers \& Education, 125, 327-344. https://doi.org/10.1016/j.compedu.2018.05.019

Dover, A. G., Kressler, B., \& Lozano, M. (2020). "Learning Our Way Through": Critical Professional Development for Social Justice in Teacher Education. The New Educator, 16(1), 45-69.

Evans, D. J., Bay, B. H., Wilson, T. D., Smith, C. F., Lachman, N., \& Pawlina, W. (2020). Going virtual to support anatomy education: A STOPGAP in the midst of the Covid-19 pandemic. Wiley Online Library.

Fox, J. E., \& Schirrmacher, R. (2014). Art and creative development for young children. Cengage Learning.

Garbe, A., Ogurlu, U., Logan, N., \& Cook, P. (2020). Parents' experiences with remote education during COVID-19 school closures. American Journal of Qualitative Research, 4(3), 45-65.

Ghosh, R., \& Jing, X. (2020). Fostering Global Citizenship Through Student Mobility: Covid-19 and the 4th Wave in Internationalization of Education. Beijing International Review of Education, 2(4), 553-570.

Hao, Y., \& Lee, K. S. (2015). Teachers' concern about integrating Web 2.0 technologies and its relationship with teacher characteristics. Computers in Human Behavior, 48, 1-8.

Harrington, C., \& Thomas, M. (2018). Designing a motivational syllabus: Creating a learning path for student engagement. Stylus Publishing, LLC.

He, Y. (2014). Universal design for learning in an online teacher education course: Enhancing learners' confidence to teach online. MERLOT Journal of Online Learning and Teaching, 10(2), 283-298.

Huang, R., Liu, D., Tlili, A., Knyazeva, S., Chang, T. W., Zhang, X., Burgos, D., Jemni, M., Zhang, M., \& Zhuang, R. (2020). Guidance on open educational practices during school closures: Utilizing OER under COVID-19 pandemic in line with UNESCO OER recommendation. Beijing: Smart Learning Institute of Beijing Normal University.

Huda, M., \& Teh, K. S. M. (2018). Empowering professional and ethical competence on reflective teaching practice in digital era. In Mentorship Strategies in Teacher Education (pp. 136-152). IGI Global.

Jena, P. K. (2020). Online learning during lockdown period for covid-19 in India. International Journal of Multidisciplinary Educational Research (IJMER), 9.

Jolliffe, A., Ritter, J., \& Stevens, D. (2012). The online learning handbook: Developing and using web-based learning. Routledge.

Luo, T., Murray, A., \& Crompton, H. (2017). Designing authentic learning activities to train pre-service teachers about teaching Online. International Review of Research in Open and Distributed Learning, 18(7).

Rahmat, A., Syakhrani, A. W., \& Satria, E. (2021). Promising online learning and teaching in digital age: systematic review analysis. International Research Journal of Engineering, IT \& Scientific Research, 7(4), 126-135. 
Moreillon, J. (2015). Increasing interactivity in the online learning environment: Using digital tools to support students in socially constructed meaning-making. TechTrends, 59(3), 41-47.

Muir, T., Milthorpe, N., Stone, C., Dyment, J., Freeman, E., \& Hopwood, B. (2019). Chronicling engagement: Students' experience of online learning over time. Distance Education, 40(2), 262-277.

Munyoro, P. (2014). Library and information science education and training in Zimbabwe and the paradigm shift in the information industry. [Thesis]. https://researchspace.ukzn.ac.za/handle/10413/12149

Nation, I. S., \& Macalister, J. (2020). Teaching ESL/EFL reading and writing. Routledge.

Oncu, S., \& Cakir, H. (2011). Research in online learning environments: Priorities and methodologies. Computers \& Education, 57(1), 1098-1108. https://doi.org/10.1016/j.compedu.2010.12.009

Palloff, R. M., \& Pratt, K. (2013). Lessons from the virtual classroom: The realities of online teaching. John Wiley \& Sons.

Pandey, D., Ogunmola, G. A., Enbeyle, W., Abdullahi, M., Pandey, B. K., \& Pramanik, S. (2021). COVID-19: A framework for effective delivering of online classes during lockdown. Human Arenas, 1-15.

Panigrahi, R., Srivastava, P. R., \& Sharma, D. (2018). Online learning: Adoption, continuance, and learning outcome-A review of literature. International Journal of Information Management, 43, 1-14.

Powell, A., Watson, J., Staley, P., Patrick, S., Horn, M., Fetzer, L., Hibbard, L., Oglesby, J., \& Verma, S. (2015). Blending Learning: The Evolution of Online and Face-to-Face Education from 2008-2015. Promising Practices in Blended and Online Learning Series. International Association for K-12 Online Learning.

Papavlasopoulou, S., Giannakos, M. N., \& Jaccheri, L. (2017). Empirical studies on the Maker Movement, a promising approach to learning: A literature review. Entertainment Computing, 18, 57-78. https://doi.org/10.1016/j.entcom.2016.09.002

Putra, P., Liriwati, F. Y., Tahrim, T., Syafrudin, S., \& Aslan, A. (2020). The Students Learning from Home Experiences during Covid-19 School Closures Policy In Indonesia. Jurnal Iqra' : Kajian Ilmu Pendidikan, 5(2), 30-42. https://doi.org/10.25217/ji.v5i2.1019

Rapanta, C., Botturi, L., Goodyear, P., Guàrdia, L., \& Koole, M. (2020). Online university teaching during and after the Covid-19 crisis: Refocusing teacher presence and learning activity. Postdigital Science and Education, 2(3), 923-945.

Raskind, I. G., Shelton, R. C., Comeau, D. L., Cooper, H. L., Griffith, D. M., \& Kegler, M. C. (2019). A review of qualitative data analysis practices in health education and health behavior research. Health Education \& Behavior, 46(1), 32-39.

Raut, A. (2020). Education for all: new paradigm and e-learning. New Paradigm in Business \& Education, 7.

Robles, A. C. M. O. (2013). The use of educational web tools: An innovative technique in teacher education courses. IJ Modern Education and Computer Science, 3, 34-40.

Sadaf, A., Newby, T. J., \& Ertmer, P. A. (2012). Exploring pre-service teachers' beliefs about using Web 2.0 technologies in K-12 classroom. Computers \& Education, 59(3), 937-945.

Sahlberg, P. (2021). Finnish Lessons 3. O: What Can the World Learn from Educational Change in Finland? Teachers College Press.

Seels, B. B., \& Richey, R. C. (2012). Instructional technology: The definition and domains of the field. IAP.

Simamora, R. M. (2020). The Challenges of online learning during the COVID-19 pandemic: An essay analysis of performing arts education students. Studies in Learning and Teaching, 1(2), 86-103.

Sudarmo, Nugraha, M. S., Mardhiah, R. I.liow, F. E., \& Aslan. (2021). The Identification of Online Strategy Learning Results While Students Learn from Home During the Disruption of the COVID-19 Pandemic in Indonesia. Journal of Contemporary Issues in Business and Government, 27(2), 1950-1956. https://doi.org/10.47750/cibg.2021.27.02.205

Tsai, Y. H., Lin, C. H., Hong, J. C., \& Tai, K. H. (2018). The effects of metacognition on online learning interest and continuance to learn with MOOCs. Computers \& Education, 121, 18-29. https://doi.org/10.1016/j.compedu.2018.02.011

Tafazoli, D., Parra, M. E. G., \& Abril, C. A. H. (2017). Computer literacy: Sine qua non for digital age of language learning \& teaching. Theory and Practice in Language Studies, 7(9), 716-722.

Wanner, T., \& Palmer, E. (2015). Personalising learning: Exploring student and teacher perceptions about flexible learning and assessment in a flipped university course. Computers \& Education, 88, 354-369.

Young, S., \& Bruce, M. A. (2011). Classroom community and student engagement in online courses. Journal of Online Learning and Teaching, 7(2), 219-230.

Yuan, L., Powell, S. J., \& Olivier, B. (2014). Beyond MOOCs: Sustainable online learning in institutions. 
Zhao, P., Hoi, S. C., Wang, J., \& Li, B. (2014). Online transfer learning. Artificial Intelligence, 216, 76-102. https://doi.org/10.1016/j.artint.2014.06.003

Rahmat, A., Syakhrani, A. W., \& Satria, E. (2021). Promising online learning and teaching in digital age: systematic review analysis. International Research Journal of Engineering, IT \& Scientific Research, 7(4), 126-135. https://doi.org/10.21744/irjeis.v7n4.1578 